\title{
Financial Evolution and Central Bank Credit: Ethics, Morals, Taxation, Stagnation and Bank Holidays
}

\author{
Niccolo Caldararo \\ Department of Anthropology, San Francisco State University, USA \\ E-mail: cald@sfsu.edu
}

Received: June 3, 2016

Accepted: June 29, 2016

Published: July 7, 2016

doi:10.5296/ifb.v3i2.9682

URL: http://dx.doi.org/10.5296/ifb.v3i2.9682

\begin{abstract}
Since the credit crisis of 2007-8 the global economy has been in a stagnant condition, with little growth, little wage increase (Gordon, 2014), but a division in asset devaluation, with oil collapsing in recent years and many other commodities, likewise losing ground while gold and stocks rising or holding steady. Fearing a repeat of the Great Depression, economists, led by Ben Bernanke, a scholar of the Great Depression, acted to save the finance industry and create sufficient liquidity to reverse a catastrophic drop in the stock market (Bernanke, 2015a; 2015b). The strategy since 2009-10 has been to continue this liquidity, while attempting to stabilize banks. While no Great Depression-like destruction of value or massive unemployment took place (or only a short temporary one in some views), little success in overcoming stagnation has taken place with only very low growth. This article discusses the importance of destruction, especially in banking and finance, and identifies the central problem as a lack of opportunity for capitalist evolution strangulated by central bank and government action and the American form of anacyclosis, yet mediated by what can be identified as Durkheim's social condensation process.
\end{abstract}

Keywords: Credit crisis, Banking, Great Depression, Great Recession, Iceland, Ethics, Morals, Stagnation 


\section{Introduction}

It is generally accepted that quick action by the government of Iceland prevented a widespread and continued crisis there compared with the rest of the global economic environment. The failure of Iceland's banks and the refusal of the government to save them produced an interesting context to study the role of banks in recovery. Are the banks the central problem, can recovery take place without them? The situation in Iceland seems to produce affirmative answers to both questions (Thomsen, 2011; Antoshin et al., 2015).

The people of Iceland did not go unscathed as incomes dropped to comparative Great Depression levels, though not in 1930 dollars as shown by IMF figures yet GDP has recovered better than many other countries with similar banking disasters (see chart 1). Controls were placed on transfers of credit both internal and external and continue today. As the crisis unfolded in Iceland banks in the UK were being nationalized as they failed including Bradford \& Bingley. Banks were placed under administration by the government and all deposits were guaranteed. A government Treasury holding company was set up to be a vehicle for collapsing banks. Private interbank facilities were closed down. Icelandic banks had many overseas assets and liabilities including UK depositors. The government froze transactions while the condition of banks could be assessed. While consumption is "subdued" according to the IMF, current account balance is rising and Iceland's Net International Investment Position and GDP have risen substantially. Gross debt as a percentage of GDP is below Eurozone averages, yet the IMF argues that by most indicators Iceland has "recovered" (Hammar, 2015).

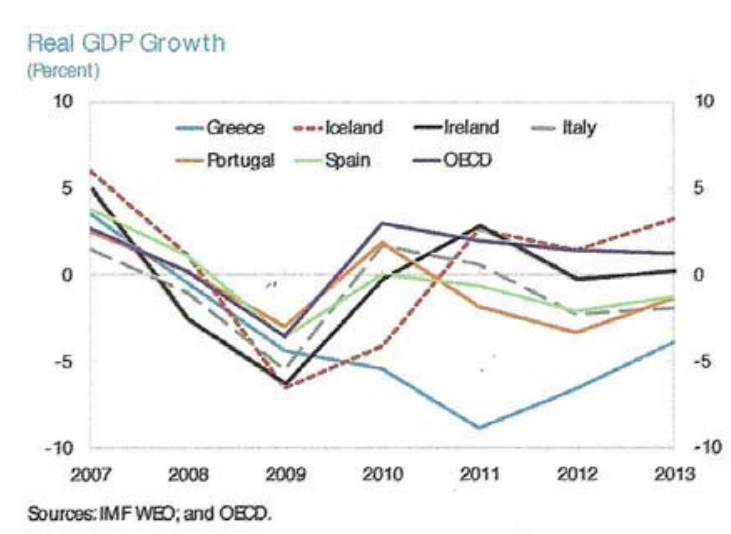

Figure 1. Iceland compared changes in GDP

Source: IMF/World Bank

What can we learn from the contrast between Iceland's experience, that of Western Europe and that in America, as well as most of the rest of the developed world (including many so-called “emerging market” nations like Brazil and China)? In these countries, with the 
exception of the United Kingdom, central banks rescued the financial industry instead of making them suffer the consequences of the disaster they caused (Mian \& Sufi, 2015). In the United Kingdom a few banks were seized or allowed to fail as in the USA, but in general the financial industry was bailed out, in the USA with the TARP program and then later purchases of bad debt in a process thinly veiled as providing liquidity (Greenspan, 2014; Paulson, 2010).

This too was a magical process as the US government's sponsored enterprises or GSAs (Freddie Mac \& Fannie Mae) have been sucking up mortgages arranged by private banks and other lenders to promote homeownership since they were created in 1970 and to produce a secondary market for mortgages. In an original form of Asset Backed Securities, the GSAs have been securitizing loans for over 40 years and offering insurance to guarantee the market. Essentially this has been a socialized loan industry with the government getting all the risk. Like the ancient Celtic sin eater, the GSAs are filled with the garbage of the real estate market and they blew up after 2008.

At the present time we can see a return of this situation as debt has risen in China and there is plenty of liquidity, yet there is a falling confidence in the system made evident by the increasing time between billing and payment to suppliers (Wildau, 2016). China's number of bad banks is swelling and defaults are rising (Wildau, 2016a), as has the use of bonds and the market in "pledge-style repros" (short term, bond-backed loans) (Hughes, 2016) making for an increasingly unstable and brittle financial system. Generally Moody's the rating agency, has found that more companies were downgraded to junk status in the first 3 months of 2016 than all of 2015 (Lewin, 2016).

We can see the same situation across the globe and rising debt in emerging markets is most disturbing, as in Brazil, with declining payment (Wheatley, 2016). In both cases falling trust is a great danger which we will discuss later, but tied to this is the increasing reports of fraud by major corporations especially banks, but recent disclosures of Toshiba's writedown of Westinghouse due to an accounting scandal (Inagaki, 2016) adds fuel to the fire. The enormous fraud of Volkswagen and other diesel car studies, including Mercedes-Benz, General Motors' Opel (Brunsden \& McGee, 2016) Mitsubishi (Doctor, 2016), further undermine consumer faith and citizen trust.

Larry Summers, former President of Harvard and financial advisor to the Clinton administration, with associates Cerutti \& Blanchard, argued in a paper in 2015 that they found by reviewing financial data over the past 40 years that recessions in advanced countries are associated with lower growth following recessions. They called this phenomenon, after a process in physics, "hysteresis," or a time-based dependence of a system's output on present and past inputs. A "rate-dependent" hysteresis occurs when there is a dynamic lag between input and output. But generally in physics, how durable the memory effect of hysteresis depends on the nature of the system, the type of deformation and the internal condition of the system. Blanchard (2016) believes that the hysteresis will dissipate and the economy will undergo continuous slow growth. This assumes recovery in the system, correction of the source and a lack of continued deformation. Instead we are seeing the same kinds of 


\section{Macrothink}

deformation from the process of financialization, with debt rising, risk extended and instability created by regional conflicts and rising political turmoil and paralysis, especially in the developed countries. This process of increasing debt instruments has had a detrimental effect on business in general in the USA according to Foroohar (2016). She finds that selling financial services, simply moving money around, produces 5 times the revenue as could be earned in the immediate postwar period (Foroohar, 2016a). The crisis in the price of oil can be assumed to be a shock limiting recovery and since it is tied to a number of political conflicts (e.g., EU, USA and UK vs Russia and the Ukraine; Saudis and Iran), resolution is likely to be limited. Yet many banks are engaged as trading platforms, as the case with Goldman Sachs (Meyer, 2016) and are trading more oil than oil companies like Exxon and Chevron. Hedging oil prices has moved not only into buying insurance as in futures, but in storing oil on the seas in an increasing number of ships as floating storage units (Nightengale \& Christie, 2015).

\section{Recoveries or not: Everywhere You Do Not Want to Be}

In the eight years since the 2008 credit collapse governments and central bank economists have attempted to return the economy to normality, yet growth is stagnant and while employment is up, that is only achieved by ignoring the participation rate which remains at post1960s lows (see Chart from the US Bureau of Labor Statistics). While some see this as irrelevant given

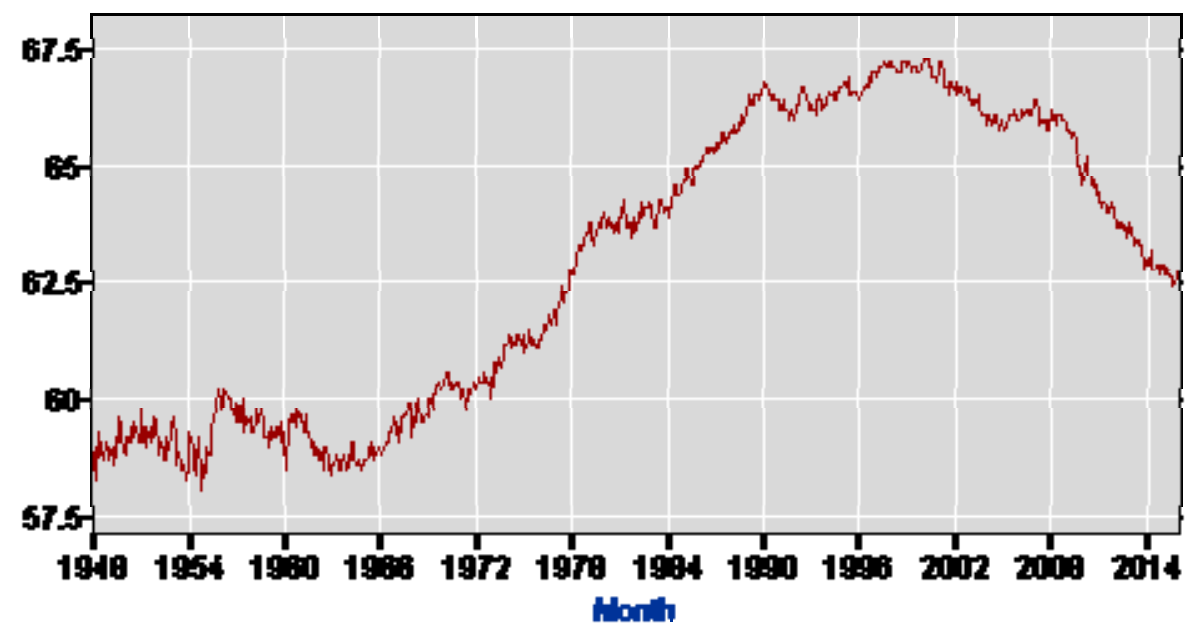

Figure 2. U.S. Participation rate

That the participation rate was lower during the growth surge of the 50s and 60s, that can reflect underemployment due to racist and sexist attitudes, though this is not supported by OEDC data (http://stats.oecd.org/Index.aspx?DatasetCode=LFS_SEXAGE_I_R) and participation rates seem to be a reflection of cultural attitudes about work. Some countries today have very high participation rates, as in Europe in the $70 \%$, while others have very low rates, in the $50 \%$ so arguments that demographic changes (low birth rate and retirements) are 
to blame are unlikely (Mercer, 2014). For example, Australia, Austria, Canada, Denmark, Germany, Iceland and the Netherlands are all over $72 \%$ and have low fertility rates and high retirement rates, while Spain, Hungry, Italy, South Africa and the Slovak Republic contrast in both. Certainly available capital and labor skills and investment rates are all central factors, these rates have been relatively stable since the beginning of the Great Recession (OECD. StatExtracts, 2014).

The achievement of producing liquidity has only manifested itself in preventing wholesale deflation in assets as happened in the Great Depression and in preventing massive unemployment by providing cheap credit to the firms that would have failed, so cheap that interest rates across the globe are at either near zero or in negative territory. This has kept many companies' profits up at the same time fear of the recession has pushed wages and full-time jobs with benefits down (NELP, 2014). But in recent quarters (2016) profits have fallen, not just in the west (US, UK and EU) but in Japan, and in all cases, the stock markets have only slightly dipped or actually risen, the opposite of what is expected. So it seems that current central bank liquidity is mainly producing asset preservation and not growth. It is economic repression on the savers of the middle class, as some in Germany are complaining (Jones, 2016), but increasing world inequality at the top wealth owning $1 \%$.

Yet the growing inequality between the $1 \%$ and the $99 \%$ is only one reason why the nation (and world) needs to have a dialogue on the nature of compensation. Before the credit crash in 2008, Partnoy (2005) addressed this issue regarding bank employee bonuses and other forms of earnings as compared to stockholder return. For one company, and not unusual at the time, on average shareholders received $\$ 1$ for every $\$ 4$ paid to employees. There needs to be a redefinition of return of service in every occupation from bankers and lawyers to doctors and ditch diggers in order to rationalize compensation to meet actual value produced by skill. Certainly it is a part of the theory of capitalism that no one is guaranteed a return on investments any more than a gambler is on a bet or farmer is guaranteed a full harvest, yet the financial industry has garnered a controlling power over the greatest segment of productive return and it is having destructive consequences, not just in greater instability in markets, but in inequality (Partnoy, 2003; 1997).

The only way this credit has been possible to extend by governments is by creating it from nothing, it is magic and I outlined the history of this process in an earlier book and papers (Caldararo, 2004; 2009a; 2009b). It is not just credit that is magic, but value which is a temporary state established, usually between two humans. The value of your house can change dramatically within a month or year depending on national and international factors, not only limited to the value of the dollar to the yen, but the balance of trade between nations. The central mechanism is to keep the spirits of the nation, especially those who own most assets from tumbling and here the stock market is central. It is like a Durkheimian god, as it goes up we are showered with good things, when it goes down, panic and terror are abroad (Caldararo, 2011). Preventing bankruptcies was also significant and the cheap credit from the Fed accomplished this task as well. In 1981 Ben Bernanke wrote an article on this issue arguing that this was a widely held idea that bankruptcies promoted recessions, but he concluded that all the evidence did not support the assertion. Corporations that were able to, 
borrowed cheaply and bought up their own stock price, limited ownership (Strumpf, 2014) as well as purchasing other companies. This has resulted in high spending levels, stagnant or falling income for corporations and increasing debt (Authers, 2016).

In general, however, we save the banks because we fear them and expect panic and poverty if they fail (Caldararo, 2013). While the world did not end when FDR closed the banks and instituted the Bank Holiday, people equal bank failures and government intervention with economic chaos. But it is the banks themselves and the conditions their organization as institutions produce that are the cause of the crises and not government intervention. We might consider the rapid rise of American industry and trade during the 1790s where America lacked a banking industry with only a handful of state banks in existence. As Shultz \& Caine (1937) note ventures and businesses were started on individual frugality and the rise of industry and trade "reflects an astounding self-stimulated and self-maintained expansion of capital." One might argue that the scale was so small it could only take place in this manner on limited basis, but today with a variety of ways people can lend (Peer to Peer, crowd sourcing, etc.) we may be entering another level of scale where it can again flourish.

Wolf rightly argues (2016) that negative rates are only a symptom, or a poor treatment for present global economic ills. However, he is wrong that it is a result of too much saving. Rather it is a result of depressed wages since the 1970s and tax avoidance and tax promotion of off-shoring jobs. Depressed or stagnant wages, as he has argued in previous articles, would have reduced the purchasing power of American workers, but increased borrowing, driven by low interest rates pushed by the Federal Reserve under Greenspan, drove levels in both spending and purchasing of homes by families whose income could not support the debt (Mian \& Sufi, 2014; Zetner \& Campbell, 2014).

\section{Debt, Tax and Tax Evasion, Modernity and "Fair Share"}

The so-called Panama Papers, leaked tax documents from the firm of Mossack Fonseca provide a vivid window to the mindset and ideology of those involved in creating and using such "shelters." Fonseca, one of the founders of the firm, argued that the work his firm has done was entirely legal and that his firm was just providing means for people to have security and privacy (Webber, 2016). It is clear, however, that the shell companies his firm set up, with major banks like HSBC, Coutts, Rothschild, UBS and Credit Suisse, were engaged in money tax evasion, and perhaps also laundering (Houlder \& Dunkley, 2016). The Mossack Fonseca law firm also falsely used the name of the Red Cross and other charities to hide money (Satter, 2016).

In the same vein, Pink (2016) (a professional in this area of tax liabilities) believes that the amount of "fair share" tax that one should pay must be related to the amount of value they receive from the government in services (roads, protection, etc). This is a common libertarian view. However, what one finds in the criminal justice system is people who rob others, banks, cheat and engage in other crimes like fraud, usually consider their "take" profits in just the same way one does who is an investor or banker, they do not want to share it with the government or anyone else. This is not to say that everyone is a crook, but rather that society functions best when there is a sense of fair play and relative opportunity. That is why most 
traditional societies function under the concept of Limited Good. This is described by Foster (1965) as an "image" most often seen in peasant societies. There is only so much of "good" to go around and so the distribution of wealth maintains order by limiting inequality and promoting the general wellbeing, often requiring sanctions of various kinds. Nevertheless, as a study of documents provided to the Financial Times have shown (Burgis, 2016), banking is facilitating criminal behavior, not just in tax avoidance, but as a vehicle of legitimacy undermining ethical procedure in business.

Where we have inequality, and especially great inequality, we have constant violence to maintain it (as in the caste system in India, Dumont, 1970) and religion as in the piety forms of indigenous Polynesia, as well as low productivity and poor overall conditions of the commons. Yet Mr. Pink complains that the tax system is "capricious and arbitrary" but it is only so due to the machinations of tax lawyers and accountants who encourage tax evasion and create complicated vehicles to avoid or hide taxable wealth, as we now see with the Panama Papers. These efforts, while fashioned in legal fictions that border (and often cross) legality as we have seen recently in offshore tax havens, undermine tax compliance by the mass of people. Such refusal to contribute to the support of social needs will eventually lead to social unrest, violence, instability and the kind of decline that historians like Rostovtzeff (1957) and Tainter (1988) described undermined the Roman Empire. Though the production of new means of distraction, as in social media, and new forms of employment associated with the information industry (from coding to Uber) seem capable of staving off such tensions. Durkheim (1938) suggested that the increase in population and new technological means would lead to greater divisions of labor and their elaboration, driving innovation and knowledge in a repeating cycle. The limits of this idea are displayed in history as war, repression and ideological forms of internal war (Inquisition, Wars of the Reformation, colonialism and revolt as today in ISIS see: Caldararo, 2015).

In a comprehensive study of tax history across Europe and the USA over several centuries, Scheve \& Stasavage (2016) find that there has been considerable variation in taxation, especially in rates and in purpose of tax, from war preparations and to carry out war, to disease as Cipolla (1976) noted over a similar period for Europe (Caldararo, 2012).

In the USA tax flight to low tax states has increased with over half of all US public companies registered in low tax Delaware. But related to this is the fact that Delaware is also a state where its laws favor corporate boards and shareholders, shielding them from responsibility (Kamar, 1998).

Added to this debt was borrowing for military invasions by the Bush Presidents, father and son, furthered by Clinton and continued by Obama. Military spending is not investment in either training or hardware as it is operation specific in most training and destroyed in most operations. Productivity thus was also reduced, when in both cases the money, financialization of borrowing and military spending, could have used to reduce the debt for productive investment. Greenwood \& Scharfstein (2013) show that the financial services share of GDP has risen from 2.9 in 1950 to 8.3 by 2006. This explosion of the share of wealth produced can be seen as one element in the strangulation of wages for the average worker and 
investment in general (Cecchetti \& Kharroubi, 2012). One can wonder over the continued concern for productivity in general, however, as an eternal treadmill of making things (the classical economist's measure of happiness=more things, seen, for example, in Spencer's version, 1933) to Durkheim's (1895) idea that productivity (desire for more things) is a consequence of the ability to make more and not, therefore necessarily associated with happiness. Toleration of waste in capitalist countries is an obvious example of this perversion of value. Things are produced with the hope of profit and are destroyed with this hope fails, just as overproduction (as in milk and other agricultural products) can be "cured" by the destruction of surplus to produce want, as China's farmers did this last February, and reported by Bloomberg (Mulvany, 2015) for US farmers.

\section{The Growth of Financial Services (value added shave of GDP)}

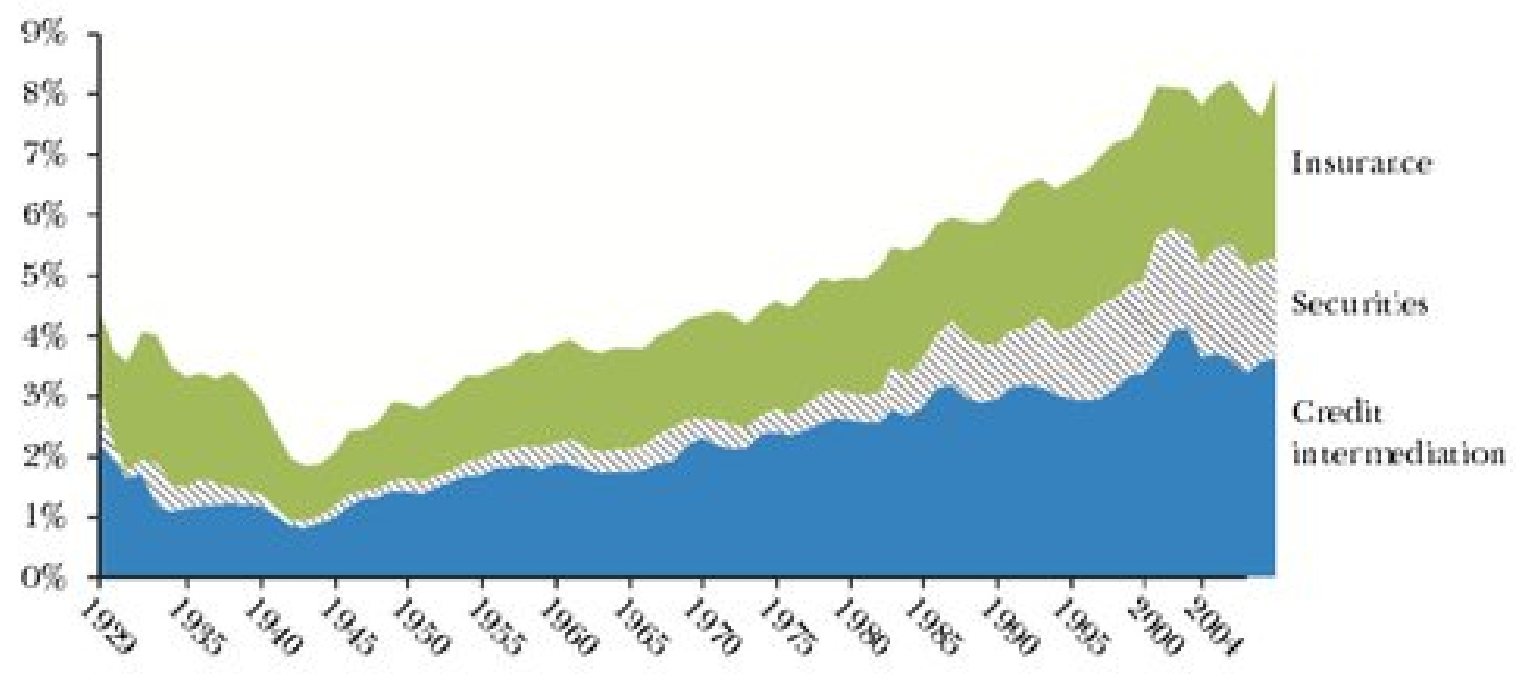

Figure 3. From Greenwood and Scharfstein, 2013

Cheap money has also kept too many businesses and banks alive that should have been allowed to fail (as noted above), so no or little capitalist evolution could take place acting as a block to productivity as well as a claim on money to stay alive (Schumpeter, 1939). Its effect siphons off reinvestment into new facilities and products. Andrew Lapthorne of Sciete Generale is quoted as noting (Authers, 2016) that US corporations are spending too much "over 35\% more than their gross operating cash flow, the biggest deficit in 20 years of data and are using debt issuance to make up the difference.” As profits dip, companies have been borrowing to buy stock and the central banks have been buying up these loans in a miraculous circle (Samson, 2016). Trim Tabs a company that tracks uses of corporate cash found that US companies have bought back $\$ 182$ bn of their own stock this year, about half of last year's purchase of \$354bn. In acquisitions Ned Davis Research found that S\&P 500 companies spent $\$ 375$ bn on acquisitions in the four quarters to the end of last September 
43\% higher than in 2007 just before the credit crisis (Authers, 2016). Goldman Sachs' economists (Garzarelli, 2016) believe this debt will not be unwound for another decade, nor be rolled over or create other credit burdens, but will be reinvested (as the central banks argue) until normalization occurs in nominal policy rates, yet in the meantime will support low levels of job creation and retail inflation.

This lack of foresight is not new, in a prescient paper published before the Enron/dotcom collapse in 2000, DeLong (2000) summarized the problem of monetary policy. Given the dilemma of our current economic situation (recovery, recession, etc.?), it is interesting to revisit his comments. Sam Fleming ("US jobs market still shy of full strength," Financial Times July 3, 2015) addresses concerns over the poor participation rate and we find investment (CAPEX) unresponsive while debt is rising along with M\&A and bonds, while there is little change in wages. This is reflected in DeLong's assessment where he states, "The proposition that the most policy can aim for is stabilization rather than gap-closing was the principal message of Friedman (1968)." Thus Friedman would be happy to see that his observation plagues us today, while central banks have been able to stabilize the world economy by producing vast amounts of liquidity, this has not created an "out" and "growth" has only been financial and has left unaffected the gap in productivity and consumption.

Inequality has risen also due to cheap money maintaining asset values (oil and some commodities excepted) when they should have fallen (as in property). At the same time there has been a substantial drop in the velocity of money (the rate of its circulation) (Minerd, 2016, Federal Reserve Bank of St. Louis, 2016). This should be having a deflationary effect as each dollar produces less economic activity in most economic textbooks, but the current situation is being distorted by more and more credit being poured onto the world economic system. That should produce an inflationary effect. But it is mainly having the effect of transferring ownership of wealth as inequality increases through a variety of uses of cheap credit, as in companies buying up their stock. While a comprehensive study of world stock markets and liquidity (Blau, 2015) found that liquidity reduces poverty and decreases income inequality, current expansion of liquidity is having the opposite effect. Though the nature of inequality seems to have a distinctly modern pattern and increasing with financialization (Piketty, 2014). 


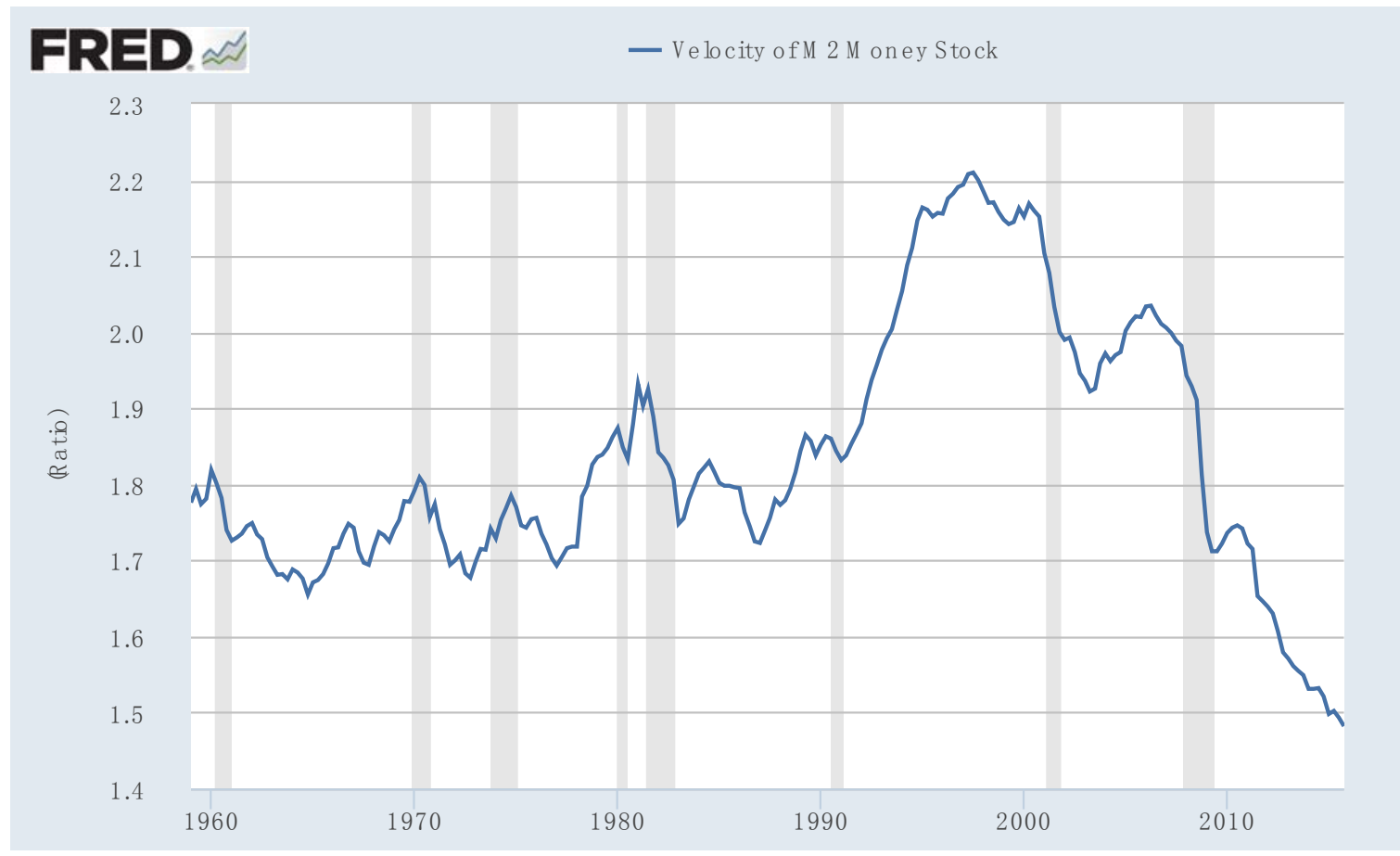

Figure 4. Velocity of M2 money stock

Source: Federal Reserve Bank of St. Louis

All traditional societies had means to limit the unequal distribution of wealth. Some of these were derived from custom, while others were structured by religious dogma and sanctions. It is a shame that most economists (both socialist and capitalist) of the 20th century regarded capitalism as a modern phenomenon, when we can see its existence in many societies of the ancient historical period, and among traditional societies, as Herskovits so clearly demonstrated in his book, Economic Anthropology published in 1952. For example, Ancient Egypt was a market economy of credit instruments, money and contracts enforced by law. I have given other examples for the existence of derivatives in ancient and traditional society in recent articles and chapters in books (Caldararo, 2009a, 2009b, \& 2011).

This clothing of modern society in special garb to separate it from past economies is unfortunate as it prevents us from making useful comparisons of societies under stress ancient and modern. The idea of modernity is really the hubris of any contemporary society (Goody, 2004). We might recall that to Adam Smith capitalism was clan warfare. He clearly describes that when one clan, whether of mercantilists, bankers or guilds gained the upper hand in an economy and controls the government, then the economy becomes influenced and out of balance, wealth and trade become constrained and distorted by the interests of the dominant group. The history of monopoly he gives and we have seen since amply attests to this scenario (Smith, 1776). This is the situation we face with the banks, they have amassed too much power and control and their present structure and complexity as well as size undermines evolution of capitalism. Their collective clients and stakeholders have too much claim on the surplus of global economies and are a significant drain on future development 
whatever form that takes.

In modern capitalist countries the distribution of wealth has generally been poorly regulated by attempts at wage and price controls and consumption laws that usually only affect the middle and lower classes. Taxation has been more effective depending on enforcement and the tax structure. The most referred to discussion on this is Ricardo (1817). Generally, however, most societies, ancient or modern fail to deal effectively with inequalities in wealth and taxation is shifted onto the lower classes resulting in diminishing returns and unrest as I have shown in Caldararo (2014). Tainter (1988) comes to a similar conclusion in his Collapse of Complex Societies, though we disagree on the role of taxation.

As in examples from past civilizations, we have seen since the 1980s the tax burden shifted in America to the middle and lower classes and the inequality of wealth has skyrocketed. Some conservative websites argue that the share of the Federal tax burden rose for the highest earners (http://www.taxfoundation.org/...). This obfuscates the situation for it is a means of deflecting attention from the tremendous increase in wealth of the highest earners at a time when most Americans have seen their incomes stagnant. Also, it confuses the role of taxation and spending. If you have 100 tax payers who each pay $10 \%$ of their income and that raises $\$ 1000$ which is the necessary amount to pay for expenditures, then your tax income is sufficient no matter how the rate affects the remaining income of each percentile of taxpayers. If however, you decrease the tax rate on all taxpayers so that the resulting tax proceeds only cover half the expenditures then you have a deficit and this is what has happened since the Reagan administration. Decreased tax rates have not resulted in increased tax proceeds to cover expenditures which were/was the Reagan theory. As Patricia Becker has shown in a book in 2006 the income of the highest earners has increased 3 times as fast as the lowest percentile and this has only become more divergent since 2006.

Therefore, the amount of that tax relative to the increase in their wealth of the highest earners declined as the percentage of the lower 95\% of earners fell as did their relative earnings. When other taxes are considered, property, sales and transfer taxes, for example, the relative tax burden fell even more significantly on the lower 95\% (http://www.huffingtonpost.com/...480.html).

The lack of tax revenue due to tax cuts over the past 30 years has created huge deficits for the federal and state governments as well as many localities, thus the anti-tax mentality has been destructive to the fiscal responsibility of the citizenry. The idea that the richest earners are using their income to create jobs is also a questionable argument, they are placing it increasingly in speculation and off-shoring it. When we take note of articles like that by Richard Dobbs and Michael Spence, "The era of cheap capital draws to a close," in the Financial Times February 1, 2011, their idea that a "30 year era of progressively cheaper capital” being replaced by an era of financial protectionism posits a result of capital scarcity, and an end to growth. This is a theoretical argument that is not supported by history. But it is a prediction of how investors are feeling. Bernstein Research reported in October of 2011, cited in the Financial Times, that there has been a stunning drop in investment in research and development since a high in 1997. 
Martin Wolfe reported that gross investment in the UK and USA has fallen to the lowest level in 3 decades. Venture capital is at a low as well as people are fleeing real investing and placing their money in non-traditional funds e.g., Fintech (H2 Ventures and KPMG, 2016), Forex speculation and other non-productive vehicles. At the same time hedge funds have been taking a beating and some have switched to alternative existences like Blackstone's move into property investment (Sender, 2016). The really troubling effect of the lack of equity in taxation and income has been the replacement of income for the lower $95 \%$ by debt. Yet the difference between reported earnings and audited balance sheet data (that is, the GAAP or Generally Accepted Accounting Standards) has grown dramatically in recent years, leaving many economists uncertain over actual profits (Lahart, 2016). For 380 S\&P companies who had reported non-GAAP increases in income of 6.6 percent, when subjected to GAAP analysis demonstrated actually 11 percent declines in income (Ford, 2016).

As their incomes became stagnant from the 1970s to the present, the lower earners replaced income increases with either credit card debt or borrowing from home equity. So while the rich got richer, the rest got debt. This situation can only be corrected by revising the tax code to make it take into account rising incomes of any segment of the economy. As societies become more unequal in wealth they become less stable. This result has followed with the French Revolution of 1789, the Russian in 1917 and in 1989 as well as the recent crises in the Middle East. Currently the financial industry holds the seat of dominance Adam Smith warned us about, and their influence is destructive and should be ended to restore the balance of the market place. Indeed, Norfield (2016) in a new book argues that the financial industry is simply an extension and modification of the colonial system which has kept colonial parent countries like the UK rich. The growth of financial products and debt are an extension of the colonial enterprise.

\section{Bank Sizes, Income and Standard of Living}

At the same time Kay (2016) criticizes the bail out of the big banks arguing that Lehman was not a "big" bank, while he ignores the virtual collapse of Citbank and others that were not allowed to fail. We have embarked on a vast and expensive experiment with banking because we feared the kind of painful cleaning and clearing of the dead and wounded firms that occurred under FDR in the 1930s. The result of that experiment produced a long stable period, very much like what we have experienced the past 8 years yet decreased inequality. The banks are bigger now and we have no clear path out of stagnation, so present financial medicine is not working, yet there are no new ideas abroad, except "helicopter money." This reminds one of ideas during the Vietnam War of dropping billions of dollar bills on North Vietnam as a means of ending the war. Between 1964 and 1973 the US dropped 2.7 million tons of bombs on Laos alone making it the most bombed country in history. One wonders when defeat will become clear in the war on the 2008 credit collapse.

The GAO report (2013) on bank failures from 2008 to 2011 found that 414 insured banks failed during this period. 85\% were banks with less than \$1bn in assets. But banks and financial institutions receiving support through the TARP program and other support during the same period dwarfs these failures. Essentially the government kept American banking 
afloat (CBO, 2012). Canada followed suit to keep its banks alive (Henderson, 2012) as did the EU, UK and many other countries.

However, Wade's comments (2016) and those of Tyson (2016) both touch on the central problem. Globalism was also a theory and it has produced a vast fragile wasteland of constantly obsolete factories and workers. "Obsolete" not worn out or out of date, rather the constant search for cheaper workforces to exploit to drive down costs has produced a monumental waste of investment and resources. This was all produced by debt in expectation of profits once initial costs were amortized, but the pace of redundancy has out stripped returns. But much of this debt, is neither written off nor performing, but hanging on in lifeless pose. While all fear an end to globalism and a return of protectionism, the ideas Wade and Barker produce support reinvestment in local populations, in education, in practical training and in local markets where wages can drive consumption again. As Prof. Barker notes, the most common type of job in 29 of the 50 states is truck or delivery driver, should these people be put out of work in a short period of time by either self-driving vehicles or drones, the effect in demand on social services, on mortgages and loss of tax money in local venues not to mention individual lives will be catastrophic. The American Trucking Association (via http://TruckInfo.net/) puts the number of drivers of trucks at 3.5 million, with the Bureau of Labor Statistics putting the number of cab drivers, limo and other service drivers for $\begin{array}{lll}\text { passengers at nearly 240,000 } & \end{array}$ (http://www.bls.gov/ooh/transportation-and-material-moving/taxi-drivers-and-chauffeurs.htm) in 2014.

This brings us to the issue of earnings, consumption, wealth and standard of living. McCloskey (2014) argues that her perception of living today in America negates the lifestyle achievements of past societies and validates her idea of this being the time of the "Great Enrichment." Just because a tremendous amount of wealth has been created does not mean that most people have benefited. She asserts this is a "per head" result, but while wealth has increased so has population, so what is the evidence? By a slight of hand McCloskey diverts us from this requirement by depreciating the idea of leveling or equal distribution.

The contrary point is that while the people in her neighborhood have lots of things, the vast majority of the earth's people still lack access to clean water, sanitation, basic health care, safe food, proper nutrition and working conditions. Yet her essential assertion is an unknowable condition she presents in platitudes of the dogmatic: that we live in the best of times. Does she mean since we became Homo, two million years ago, or Homo sapiens, some 200,000 years ago? I would argue that the world population of hunters and gatherers over the past 200,000 years lived "better" than the median person today (in terms of diet, cultural richness, family life and time off). Yet the same could be said for the remarkable advance in social life and resources at the dawn of the Neolithic (Sahlins, 1972; 1988). Just because you may have the privilege of being homeless or living in poverty amidst today's wealth does not make this time better, nor do millions of electronic devices given our levels of morbidity, mental health problems and America's exploding prison population.

McCloskey draws our attention to the millions who have gas heating, cars, small pox 
vaccinations, indoor plumbing, cheap travel, but fails to tell us what percentage do and how this is better for the small portion that do have these amenities, or how these "amenities" often fail or are the source of morbidity or death as in Flint, Michigan, with the lead in drinking water crisis (NHTIP, 2016). In contrast, the Federal Reserve Household survey of July 2014 showed that a quarter of Americans are "just getting by." But inequality does effect social outcomes negatively as indicated in one measure reported by Standard \& Poor's (Bovino, Petek, \& Chambers, 2014). Often people judge the world by how they themselves live, unfortunately they assume everyone lives that way.

Wolf's review of Milanovic's new, useful but flawed book, Global Inequality (Wolf, 2016) focuses on the problems of income and not wealth. This is the central failure of such recent treatises, they ignore wealth and the standard of living. Milanovic, like most other writers on the subject that Wolf notes like Atkinson and Bourguignon, cite changes in poverty based on income. This means that if you were a craftsperson, subsistence farmer or hunter-gatherer and did not engage in the cash economy of your locality you would be considered extremely impoverished as you made no "income." The central problem here is that as an anthropologist I focus on how societies have developed institutions and cultural practices for the generations of adaptation, while most economists just work on a single investment cycle in the interests of profit and income.

World Bank figures on global poverty since 1990 utilize national estimates (http://www.worldbank.org/en/topic/poverty/overview). Surveys are based on forms filled out by villagers and urban and rural "sources" (for example, Lao PDR STEP Skills Measurement Survey 2011-2012). Analysis of these indicates a very poor response rate and most of these are refused or the individual could not read the form. Yet even so the World Bank produces these and so chirps cheerily that incomes have improved markedly since 1990, noting that in 2012 12.7\% of the world's population lived on an income of less than \$1.90 a day. Yet things are even better, that is down $37 \%$ since 1990 and $44 \%$ since 1981! But do these estimates really tell us that people are better off? What is the wealth and health of those now who are living on more than $\$ 1.90$ a day? Is their standard of living better?

In the 1970s and 1980s I did research in Mexico and in Oceania in locales where most people engaged the cash economy very little, often only trading surplus at local markets for non-local goods and a few "luxury items." They controlled their land and the resources which they extracted from it. By the 1990s this began to change vastly as global reach by companies from developed countries began to effect local governments by either investing locally or by changing policy. Government pressure to change to cash export crops or other changes in traditional methods was often disastrous. Land control was the first victim and as people lost control of the local resources they were forced into towns and cities to earn "incomes" or cash which they had to use to survive.

The World Bank acknowledges this problem as in a recent report to introduce changes in forestry practices in a South Asian country: "What the project failed to do was properly understand the livelihood realities of its intended beneficiaries to profit from their investment in 
(https://ieg.worldbankgroup.org/Data/reports/ieg_poverty_case_studies.pdf)

So people go from "poverty of riches" to "poverty of income." This is not better, it is a disease of globalism. The consequences at present include the nationalism that has driven Brexit and Donald Trump’s candidacy in America.

\section{Inflation, Wages and China}

Numerous articles in the past 4 years have discussed why we are not experiencing inflation yet none of these has been logical in the face of stagnant incomes for the lower $95 \%$ of earners in the USA (similar in Europe). A different view of the lack of inflation sees inflation not in prices of goods and services but in assets, yet there has been deflation in some segments of assets as in house prices, Asset Backed Securities, derivatives and bonds. While some of these asset classes have experienced volatility and lost and gained value, others have disappeared, becoming worthless or considered "junk." Gold has lost considerable value and can be said to be deflated. Equities have been on a general upward march in value, fueled in the opinion of many economists, by Fed policy.

As the Fed (and central banks in the EU) has increased the money supply one would expect prices to rise even with a modest increase in population, the increase in forms of money on the scale we have experienced should produce inflation. But we would also expect an increase in wages which has not happened, both over the past 6 years and in real purchasing power over the past 40 . In fact, it is also generally agreed that income inequality has grown as the central banks have increased their recent efforts.

What is taking place is a thorough depression of consumption (with the mass of workers choosing cheaper products and reducing expenditures) as wages are stagnant which depresses demand and at the same time slows hiring. This has also produced increases in productivity. It has resulted in under employment and long term unemployment for millions of people, reducing their standard of living. But while wages and income have been flat the other reason for prices to be stable is that of off shoring and global supply chains that have increased productivity by dependence on low wage locales. That produces cheap products and services at home making it somewhat possible for Americans to maintain a semblance of their prior lifestyles. That process is reaching its limits (increased wages, pollution, corruption in China and Brazil, Indonesia, etc.) as has been the case historically under all conditions of diminishing returns, though this concept has been assessed differently by various historians and economists (Hutchinson, 1967).

Prices must rise if demand does and costs cannot be reduced. Thus keeping wages low in America keeps prices low and profits up. Only it should be obvious that there can be no innovation without foundation, insight depends on education and training as well as infrastructure, and further productivity savings may maintain the present situation, or it might be extended if the collapsing infrastructure in India can be dealt with and increased labor savings extracted. How this could be distributed to sustain conditions is unclear. So there has been inflation, but it is hidden in lost wages, depressed consumption and asset volatility. Low interest rates have punished savers and low tax rates have driven money into the stock market 
and risky investment strategies. This trajectory of the global economy will soon come to a new adjustment of more severe repercussions then that in 2008-9.

But as China slows and its economy is also propped up by the government lending and liquidity devices, its financial system has ballooned and become opaque (Yang \& Wildau, 2016). At the same time its official debt approaches $247 \%$ of GDP (Lanman, 2016). A credit collapse as in 2008 would create massive failures across the globe and governments are already stretched beyond historic levels of debt taken on to save the global economy after 2009. However, if governments did not act, or were unable to equal the challenge the greatest effect would be in a crash of equities and commodities destroying vast mountains of wealth accumulated by the world's $1 \%$ at the expense of the $99 \%$. Tax shelters, avoidance schemes of all kinds and everything but perhaps insured bank deposits would evaporate.

This reset of the world's economy would be the kind of substantial evolutionary pain Schumpeter (in his 1939 book, Business Cycles) argued would be necessary to renew economies, yet the current structure of global finance might not survive. The question most politicians would raise, would focus on the expected suffering of the masses. Here "masses" means people, but what would the actual cost be? Given our current communications and the magical nature of money and credit (Caldararo, 2009b), a renewal could take place almost immediately where the transfer of new credit ledgers on electronic platforms could replace banks and contemporary financial institutions locally and then regionally. As institutions depend on habit (Hodgson, 2006) major disruptions might linger for weeks or months, but local transfers of credit for goods and services could be a matter of days. As in the creation of local money during the Great Depression, the Bitcoin world might be the phoenix that rises from the ashes of the banks.

\section{Ageing Populations, Investment, and Innovation}

But how would this affect such dependent populations as the elderly, pensioners, vulnerable members of our society? Certainly everyone imagines dystopian futures with collapse, yet this did not happen in 1929. There is no reason that a general collapse would take place, only a readjustment of value, a reset of wealth. Some ideas on the issue have recently been expressed, as in the case of a Mr. Giles. The general idea behind Giles' concerns appearing in an article "Ageing populations," in the Financial Times at the height of the credit disaster (29 December 2009) are that savings for retirement and taxes to provide for retirement services will fall short of costs. But the more significant focus should be on what is done by a society with its productivity savings. Broadberry has shown in his 1992 Discussion Paper n. 708, that trends in productivity have differed in different countries. The reflection of these trends in labor savings was remarked by Robert Heilbroner in his 1962 book. He demonstrates that by the 1960s a typical modern worker could achieve in a 40 hour week using power-driven equipment what 3 men working a 70 hour work week could 50 years before. In 1967 Baumol \& Bowen (1966) drew out his diagnosis of service industry costs and argued (called Baumol) disease that most services were labor-intensive and no innovations could reduce their diminished returns. They focused on "stagnant" sectors of the economy, but the problem here is that no one can gauge what is a "stagnant" sector until it is either transformed or overtaken 
by new methods or technology. Energy production was not stagnant in 1700 nor was information, yet no one could have predicted the engines that would use fossil fuels either or the change to computers in 1900. Yet, Baumol \& Bowen's predictions have had a mixed history. This has been proven in the globalized and information economy (Nordhaus, 2006).

So while it is no longer necessary to have the same number of workers engaged today and in perpetuity at the same work as in 1930 to be able to provide for the retirement of each cohort of workers (to amortize costs, for example of retirement), it is the allocation of productivity savings that is essential.

Theoretically, it is not even crucial that money be saved for retirement liabilities as that money can be completely lost in market crashes (as we have seen in the 1987, dot.com and current credit crisis). It is certain that our behavior is much like that of other animals who cache food for lean times. But like those animals what is saved today can be lost tomorrow not by mold or rodents, and the elements, as in caches of food, but in unwise investments and market vagaries.

As Schumpeter (1939) notes, innovations bring about economic growth and also lead to bubbles and crashes. However, without innovation to boost productivity our economies would stagnate. Financial innovations are productive in so much as they can act to direct funds that would otherwise be inactive to productive ends, but most often they are means to entertainment and gambling leading to hysteria and then panic. However, they can also act to entice people to work harder and motivate them towards innovation as bubbles accelerate. In other words, to drive people to seek riches and booms and busts do often also act to redistribute wealth from inactive holdings to engaged actors. The benefits of this transfer can often be seen in solid industrial output or research and development that is rewarded with practical advances in science and technical achievement, but most often in pursuit of pleasure or power.

We are treating productivity as a means for short term profits to engage in consumption in both prestige behavior (travel, entertainment, cars, buildings...) and in convenience consumption (packaging, air conditioning, lighting...). Increases in productivity should lead to increases in the general standard of living, in investment in innovations that will provide for each new retiring generation of workers by the increased efficiencies, rather than increased pleasure, comfort and power. Actual money in the bank is not necessary and probably counters to positive outcomes as it can lead to bubbles rather than innovation. As Combes, Lafourcade, \& Thisse have found in their paper, "Long-run spatial inequality in France: evolution and determinants," (2008), for data available to them there has been a 10-fold increase in real per capita income during the period 1860-2000 and between 1860 and 1930 an annual growth rate of $0.94 \%$ implying a doubling of the standard of living in 70 years rising to an annual average of 2.4\% during 1930-2000 doubling the standard of living in less than 30 years. Again, increases in the standard of living are subjective based on needs definition as I have shown in my book (2013a). These needs definitions are based on partly cultural values but increasingly on advertised desires. The future ability of a society to provide for its aged will be defined by the percentage it allocates to education and innovation 
and not needs production.

Pension strategies should be redefined to assess future productivity gains as means of capturing wealth to provide for retirees rather than the illusion of building up piles of money, value in stocks, i.e., the human equivalent of buried acorns.

\section{War, Avoidance and Morality}

The argument that WWII lifted the American economy out of depression is undermined today by the fact that we have been at war since 1990 in Iraq and Afghanistan with little to show in economic sustainability. War has been one factor driving the problem. At the core of the problem is tax avoidance. The USA is the world's main offender in protecting and facilitating tax avoidance (Scannell \& Houlder, 2016). From Delaware to South Dakota states and the federal government promote tax cheating, making millions of average working Americans foot the bill just to maintain basic services at a time household incomes have fallen for the majority as reported by the Pew Research Center (Fleming \& Donnan, 2016). What steps should be taken? First institute the full Unitary Tax System that would eliminate the tax advantages of domicile and erase schemes invented to hide profits. A reading of the arguments made by Barclay's bank and the US Supreme Court's disagreement and support of California's application of a limited Unity Tax can be seen at the core of today's tax avoidance catastrophe (http://www.pmstax.com/state/barclays9408.shtml). Rising interest rates and promoting investments in education and training are two secondary actions that should be taken, as the former (Unitary Tax System) will attack money parked in assets (especially risky bonds supporting zombie companies) and the latter interest rates and education will promote small business and local innovation. Other sources of delay emanate from institutions like the World Bank where loans have reached record levels, and interviews with the World Bank president and lead staff indicate that the bank is seeking more capital to increase lending (Donnan, 2016).

Larry Summers and a number of other economists, have theorized that we are in a period of no or low growth, a secular stagnation. As this process has developed there has been a concomitant increase in inequality across the globe in democracy after democracy no matter what their level of citizen participation. It has long been a tenet of western economic history that such economic stultification is associated with hierarchical societies of a singularly undemocratic structure, for example, as described by Wittfogel in his book on China (1938) but mostly known from his later study, Oriental Despotism. Here control of the society is captured by a bureaucratic elite that garners most power and wealth, creating vast inequality, yet little growth or innovation equal to our financial elite today.

Anthropologist Adam (1966) demonstrated that there was little archaeological support for the hydralic component of this theory of Wittfogel, as a causative factor. On the other hand, Schumpter (1939) attempted to find the factors that caused destructive business cycles as a means of understanding the evolution of capitalism and the dynamic nature of western economies in the 19th and 20th centuries. But one is reminded of a paper given by Kenneth Boulding while a student at Harvard, and is later developed in his book, Evolutionary Economics (1981) criticizing efforts to discover conditions of equilibrium in systems that are, 
as Dopfer (2001) noted, by their very nature, in disequilibrium. This is certainly the dilemma of the central banks. While both Schumpter \& Boulding pursued a theory of the evolution of capitalism that depends on a certain ideology of progressivism.

A more cyclical view of history, certainly harking to Vico \& Ibn Khaldun, might argue that capitalism is taking on a more aristocratic or caste structure as inequality and a decrease in upward mobility have set in. In this vein it has been strange reading of Republican and Democratic American presidents efforts' to establish democracies in various countries beginning with Reagan, when America is a representative democracy. Recent comments by various American presidential hopefuls have not clarified the American understanding of its own government, nor the benefits of democracy, representative or not.

The media is filled with discussions of inequality, of tax avoidance and innovative accounting schemes. One result of this is not only a shift of the burden of services (road repairs, bridges, education, etc.) onto the middle and working class, but a general degradation of the quality of life and investments in the future.

The cycle of wealth production and wealth preservation and social crisis does not necessarily end in revolution. As Rostovtzeff (1926) demonstrated in regard to this cycle in the Roman state, it led to civil war and the conquest of the state by a military dictatorship of the army. A significant change took place after Augustus where elected municipal councils whose responsibility for services depended on taxation, became increasingly burdened by the same kinds of shifts in wealth accumulation and avoidance as we see today, and have seen in other societies. The military dictatorship, through its various representatives, the emperors, instituted laws making the local rich responsible for providing services, these pressured peasants and violent eruptions followed, especially in places like Egypt. So the very plan of the Roman aristocratic Optimates party to destroy the constitution and seize more wealth and power, led to their widespread destruction, both in the Civil War, in the proscriptions of its aftermath and in the triumph of the military dictatorship.

The main outcome, however, the trend of this policy, was to seize the wealth of the rich by the army and the power of the state left little recourse. In the time of Emperor Septimius, Ulpian codified such efforts which had already resulted in merchants and ship owners forming corporations and going on strike to protest the actions of the government. Current trends in manipulating tax laws and off-shoring wealth and other schemes will only intensify the growth of poverty and alienation among the mass of people who make up those in the military. The outcome cannot be as rosy for the super rich as some hope.

Some of the confusion over central bank responses to the global turn down and banking problems, has been on target, as in Fleming's article ("Fed frets over growing risks to US economy amid market turmoil” FT 18 Fed, 2016). This is true across the globe as seen in the article by Wiggleworth, Lewis, \& McCrum, ("Negative thinking," Financial Times 18 Feb 2016). While banks can continue to produce credit and print money without inflationary outcome in a wage depression environment (as Martin Wolf described in his January 272016 article, in the Financial Times, “The losers are in revolt against the elites"), the use of this credit is what is essential. As Alexander Hamilton claimed in his first "Report on Public 
Credit” to the new US Congress after adoption of the Federal Government in December of 1789:

"It is a well-known fact, that in countries in which the national debt is properly funded, and an object of established confidence, it answers most of the purposes of money. Transfers of stock, or public debt, are there equivalent to payments in species; or in other words, stock, in the principal transactions of business, passes current as specie. The same thing would, in all probability, happen here, under the like circumstances.” (cited in Shultz \& Caine, 1937)

It might be said that Hamilton was the first Keynesian. What is important, as I discussed in a chapter on the recent crisis in 2009 (Caldararo, 2010), the central issue is confidence, but it must be joined with a sense of fairness which the failure of prosecutions has undermined. It is also essential that liquidity, like magic, not simply become a routinized behavior in which faith and not action result. What we have seen since 2008 is a continuation of wage depression and increased suffering in countries across the globe.

\section{The EU, Bankruptcy, US States, Money and Growth}

Mazower (2016) suggests that a view of the past history of Europe and a dedication to future evolution is necessary to find solutions for present EU economic problems. His selection of past lessons begins with the machinations of the Congress of Vienna. At the Congress, Wenzel, \& Metternich, redrew the boundaries of Europe to erase the changes introduced by the French Revolution and Napoleon. Their goal was not just to return to a past detente but to balance a weakened France that would no longer challenge other European powers. One might view the history of the EU in this fashion, but the reunification of Germany and European integration has functioned more to stabilize Eurasia from the disintegration of the Soviet Empire.

The economic problems of the EU are quite similar in some ways to the problems the young American Confederation of states experienced during and after the revolution and break from England. Without specific powers or a means of enforcing a national policy, the Continental Congress and the individual states produced coinage and paper money while foreign money (both gold and silver, including Spanish and English) circulated in the colonies and were used in individual dealings with foreign entities and merchants. The Confederation's attempts to solve the lack of cooperation on taxation and debt with the states led to default, drastic discounting of money and bonds and yet the country as a whole prospered.

The lack of a national currency was not a hindrance to trade or commerce, and while farmers and merchants often had to resort to forms of barter and paper, the economy continued to grow as Shultz \& Caine (1937) show in their book. In fact, between 1783 and 1875 $\$ 10,000,000$ of specie was in circulation from various state sources, prices were high and interest rates low, but due to a deteriorating foreign trade by late 1785 this specie amount largely disappeared. Prices fell and interest rates rose to over $25 \%$ causing panic. By 1790 , however, international trade had rebounded and by the end of the year more than $\$ 9,000,000$ in specie was in circulation again. It was not the nature of taxation or money form (silver, gold or paper) that was the foundation of positive or negative outcomes in the economy, but 
the dependence of foreign trade that created movements.

The problems Greece has with debt and the possibility of default on payments that are coming due can be seen in parallel events in US history. Most recent is the continuing dilemma over Puerto Rico, which Congress refuses to rescue and it has failed to be able to declare itself bankrupt. Several American states have been bankrupt in the past. In the early 19th century especially after the Panic of 1837, many nearly did so and the present Greek drama is similar to attempts to prevent actual failure, but after the Civil War states did fail. New York State nearly was bankrupted by the debts of New York City in the 1970s. The fact of bankruptcy has been handled in the US with a lack of uniformity and the law is vague. As Skeel has noted, "The Supreme Court has never fully defined its scope, and commentators rarely stop to examine its contours. In its most important early case, Sturges v Crowninshield, the Court made clear that the Bankruptcy Clause gives Congress the power to marshal some or all of the debtors' assets to pay its creditors, and to discharge some or all of the debtor's obligations.” This is from his article, "States of Bankruptcy," (2012). Detail on the actual bankruptcies of American states can be found in Orth (1987).

What Skeel is attempting in his 2012 article is to develop the concept of state bankruptcy in the 21st century, as in 2012 it appeared that several states, including Illinois and California had been in technical default (California's famous “warrants” being one method of pretending to be solvent). Obviously the EU lacks the technical mechanism to process a state bankruptcy, but then as Skeel \& Orth describe, neither has the US, both Congress and the Supreme Court have sidestepped this issue and left messy events to take their course. The EU parliament could produce as messy a process as the US Congress, or the EU Court of Justice could rule in as vague terms as the US Supreme Court has.

The EU is having growing pains and the American Union had similar ones in its past. What is confusing here is in Europe, for a visiting American, we find the fear over debt by member states puzzling. The fact that Greece, Iceland and Spain have spent more than they can pay as members of the Eurozone seems almost quaint to an American. In America following the Civil War most southern states have been net gainers from the Federal treasury. They routinely pay less in taxes for services and benefits they receive from the Federal budget. This has been a moral and fiscal concern in America for more than 150 years, excepting the costs of Reconstruction. It has been a moral concern as once Reconstruction failed, southern politicians used Federal funds to benefit the white minority by the Black Codes and Jim Crow laws and discrimination in a systematic racism. The fiscal concern was that southern senators (among others) constantly manipulated Federal budgets to gain more and more tax money paid by other states out of the Federal tax revenue. Another aspect of the fiscal side was a lack of accountability where Federal funds for projects for education and infrastructure were not equally available due to racism and corruption as anyone could see visiting the south in the 1960s. The history of this manipulation of the Federal budget can be found in a paper, “The President and the Distribution of Federal Spending” Berry, Burden, \& Howell (2010). This American history should be seen as a background upon which an integration of the EU can take place. 
Either way the situation of the huge debt Greece has must be dealt with as if it were a default so that the Greek economy can possibly recover. The debt cannot continue. The forgiveness of debt has a long history, is mentioned in the Bible, and was often resorted to by the Romans and many other peoples. Whether debt is forgiven, destroyed by several rituals, rational or magical means or projected into the future by longer termed financial device, is irrelevant to the end desired: a feeling of recovery among the people and a return to economic "normality." The shape of such a transition is a cultural process, where one crisis is lifted and another motivation set in place.

Not with standing current thinking on the subject, the sufferings of European economies has had more to do with banking failures and the EU economies' integration with global trade as well as the crisis in Eastern Europe and the Middle East. The EU is too dependent on its banks and their debt policies as well as international trade. The UK may benefit in the short run from Brexit, but the consequences may be costly, as in the lost of Scotland and Northern Ireland. Yet it is unclear at this point (after the vote in June of 2016) if Parliament will accept the referendum or only consider it as advisory or negotiate a partial withdrawal that other EU states will accept. One has to ask, at the risk of being considered a populist, if the European economies are better off today and more stable and resilient than they were before the creation of the WTO and other trade arrangements that globalize commerce, beginning with the Uruguay Round and Marrakesh Agreement some 30 years ago? Instead of stability, global integration has resulted in exporting jobs, and creating dependencies on overseas manufacturing and development. This is behind, at least partially the Brexit vote, as well as movements for "Out" of the EU in other nations. Those countries that have gained the most from globalization, like China, South Korea and India, have the most trade barriers to protect local industries and investment. While integration helped the American states produce a powerful central government, it did not solve the problem of money or economic panics, which raged with increasing intensity throughout the 19th century until 1929 and Glass-Steagell. Europe might benefit more from reassessing its commitment to globalism and its uncontrolled banking sector.

\section{Conclusion and Prospects}

What is striking at present is the "negative thinking" from all quarters. There are no new ideas, yet as Ris (1938) explained in his brilliant text on the history of monetary and credit theory, money, credit and liquidity do not make economies, the desire of people to exchange labor, materials and means (transportation, factories, etc.) result in markets and consumption. We lack the confidence in investors and politicians to act in the market place in such a way as to raise wages that can result in consumption. If there is confidence in the mass of the citizenry that the economy is fair and not biased against them then we can expect people will make efforts to improve their condition.

The lack of prosecutions, the bigger banks, the larger share of the economy by financial institutions all demonstrate against the idea of fairness. This must change, but it represents a particular form of what Polybius (145 B.C.E.) called, anacyclosis or cycles of freedom that degenerate into corruption. This process, known to the founders of the US republic the 
institutions of which were designed to avoid, involves the transition of government forms from effective to corrupt, from kings to tyrants who are overthrown by aristocrats or men who become so and then evolve into oligarchs whose excesses bring about democratic revolution which develops into mob rule that is transformed by the creation of order fashioned by an individual who becomes king and so on.

Polybius attributes the stability and power of the Romans, and their ability to conquer the world and manage it, to their balanced constitution between the different segments of Roman society. Other societies had failed in this and the founders of the American republic endeavored to create a balanced constitution that would benefit from the Roman experience. But, as Appian noted as he watched the Roman Civil Wars destroy those safeguarding institutions and dismember their protective constitution, the power of wealth drove men to dismantle just what had given them wealth. Americans have seen their balanced constitution also being dismantled in the same path to anacyclosis, not just in the undermining of just taxation, or in the legislation passed by the states to limit or prevent citizens to vote or in laws to allow elections to be bought by the few (Citizens United decision of the Supreme Court), but in the concentration of monopoly in media to prevent free and unbiased access to information. Part of the concentration of media outlets, as in Rupert Murdock's Fox Empire or Murphy's Liberty Media, is to produce opinion that can be used to marshal power. Competition among the $1 \%$ for power will spill over into the recruitment of client masses to contend for state apparatus (as with the Tea Party by the Koch brothers) which has translated into control of US state legislatures, governorships, the US Senate and House. This has in the past led to more violent contests for power which can enlarge to actual seizure of military force and an end to representative law based institutions.

Schipani's article on President Morales' political future and the desires of many Bolivians, brings up an interesting contrast between developing and developed economies and their political trajectories. At a time when people in developing economies like Bolivia are pressing for stronger and more institutions to stabilize their countries and guarantee their children a prosperous and safe future, we find in the USA and Europe tech giants and futurists clamoring for an end to institutions that gave their countries just these benefits. The change in labor conditions, what Katherine Stone (http://heinonline.org/HOL/LandingPage?handle=hein.journals/uclalr48\&div=25\&id=\&page $=$ ) has called the "psychological contract," is replacing the norms of working life, of promotion, employment relations in firms. Furthered by the collapse of unions it has created a working landscape where a free fall in opportunity and income has become the condition of work.

Scruton (2015 see: http://www.firstthings.com/article/2015/04/the-end-of-the-university) has critiqued some of the proposals for an end to universities, while other institutions including public schools, libraries, courts, social welfare agencies, parks and public lands (especially today in the USA) are under fire from a variety of motives and groups. These efforts might indicate the direction we are headed, not so much into the Gilded Age of the late 19th century, or the brutal period of destruction of the yeoman class so vividly described by Polanyi (1944) in the creation of the industrial society. Rather, we seem tilting back to the chaos of a feudal 
society without rights, law or order, into a venture capitalist libertarian dream world of Hobbesian competition.

What is also frustrating is the design of cities today. We find an increasingly efficient pattern of driving up prices for housing in the central cities and pushing low wage families out farther and farther into ghettoized suburbs of the poor. The time these workers have to spend to get to work in the central cities increases daily and mimics the life style of Africans in Apartheid South Africa in the 1970s and 1980s. Many women worked in city centers for white homes as servants or in other employment where they had to live in illegal housing and only visit their families occasionally. This situation was illustrated in the documentary film, Maids and Madams (1985) by Hamermesh, reviewed by Marcus (1990) and based on a book by Cock (1980). I am not suggesting that American workers suffer as African workers did under Apartheid, rather I am noting the similarity of the process by which living zones are being created for rich and working people and how these zones can limit family activities and thus impoverish relationships within the family as travel times to work and home lengthen and pay remains stagnant. These conditions are not a result of a lack of productivity by the workforce as data charted by the Economic Policy Institute demonstrate (Shierholz \& Mishel, 2013).

Therefore what is to be done? The deadlock in the world's biggest economy has only increased inequality by the GOP blocking any meaningful public spending. This must be ended. The only possible way now is by blackmail. A public spirited President could enable the Federal Reserve Board to raise interest rates to 3\% which would immediately bankrupt 10s of thousands of zombie firms only kept alive by cheap money. It would also jeopardize 100s of billions of dollars-worth of risky investment devices including junk bonds. The threat might be enough to force the GOP to invest in America's future and reduce inequality in an orderly and effective fashion.

One might question whether this is a responsible and informed proposal, yet the past decisions of "responsible and informed" bankers and economists seem, well, bankrupt today. Let's focus on two, one being Bernanke’s predecessor.

King's book, The End of Alchemy, is certainly a retelling of complex events. Mr. King seems to view banks, in their present form, as necessary vehicles for national economies at a time when we are seeing not only a wave of new forms of financial entities, but new methods of financing (e.g., kickstarter, internet lending groups) and a horizon of new forms of money and transactions (e.g., Bitcoin). While banks are inherently unstable as their history has shown (see Caldararo, 2013), they are now becoming obsolete.

We will still see currency as in fiat money in the future, but local mutuals, credit unions and savings and loans can provide the kinds of utility function banks have been useful for in the past. Banks now are gambling entities as Mr. King clearly describes, they need to bet against short term deposits in long term loans forcing them to engage in risky behavior in a process that inevitably requires government bailouts. Here King presents us with a scenario of the run up to the credit crisis based on this analysis and argues that the spending of most developing countries and borrowing was facilitated by central banks. But this fails to notice that central 
bankers could have recognized that this was unsustainable and Alan Greenspan could have put the brakes on the borrowing. What was at stake was a slower growth period after the 2000 downturn (caused by a speculative bubble which depended on cheap money as well), but that would have been preferable to what did take place.

King asserts that we need to return to high consumption rates and lower saving, though he realizes that wages have been stagnant since 1970 and that productivity has been dropping in recent years. How to increase consumption when people do not have increased income and productivity is dropping is a question that eludes most economists. It is obvious that most of the gains in both productivity and corporate balance sheets have been made by cutting jobs and hours, further depressing wages and consumption. The U6 figures demonstrate lower participation rates than in 2007 and a workforce that is underemployed when working, or working at multiple low paying jobs to make ends meet. There is little room there now for increased productivity.

King's suggestions about the new banking rules are remarkable in the context of recent experience. It is obvious that securitization is inherently destabilizing and while leveraging can be acceptable depending on the quality of design, we have too much credit based on too much abstract value of theoretical assets, not only derivatives, but underlying real assets that bonds have been created from and the loans and projected earnings on which risk assessments have been made. A simple review of the instruments (including the new ETFs) produced from 2000 to 2007 clearly shows this, yet we find the same process going on today. Junk bonds and more mergers and acquisitions based on more debt which is packaged again as assets to be sold for more leveraging creates a wonderland of finance. The "haircuts" King refers to are ok in theory but in reality the assets are already over leveraged. His idea of a $10 \%$ equity base is a fantasy as long as governments are willing to back the banks. However, if only deposits in credit unions and S\&Ls were guaranteed and the Fannie Mae and Freddie Mac GSAs were privatized again, letting the taxpayer off the hook, we might see a more prudent financial system as the risk would be almost totally on the speculator and the system would be ruled by "buyer beware" instead of government bailout. However, past history would argue that speculation would give rise to unstable conditions as bankers and investors would assume that governments would rescue them.

It has been the methodology of this paper to examine the economic history of liquidity, banking and ethics across societies, cultures and time. The general conclusions can be extracted from the initial study of Iceland's resolution of their credit crisis in comparison with other examples. It is clear that without consequences and punishments a general atmosphere of moral stasis sets in undermining expectations of ethical limits and sanctions. The "tough" medicine of the Great Depression is now lost on people as a deterrent, as are the losses in the S\&L debacle and the dotcom crash. The failure of factors of the economy to move in expected directions given current stresses as discussed above, agrees with ideas that we are severed from past ideas of normality (Caldararo, 2012; Reinhart \& Rogoff, 2009). Calls for "helicopter money" and other desperate measures with novel twists are abroad and unabashed. There remains a feeling of exception that it appears every generation now will need to experience to test the boundaries of prudence. The smoke from the ruins of 2008 has hardly 
cleared yet we are already seeing the new fires of exuberance.

\section{References}

Adams, R. M. (1966). The Evolution of Urban Society. Chicago: Aldine.

Antoshin, S., Boranova, V., Bordon, A., Bouza, S., \& Das, M. et al. (2015). Iceland: Selected Issues. IMF Country Report No. 15/73. [Online] Available: https://www.imf.org/external/pubs/ft/scr/2015/cr1573.pdf.

Authers, J. (2016). Alarm bells are ringing over corporate debt and stalled earnings. Financial Times.

Barker, T. E. (2016). Looming crisis is about technology, not trade. Financial Times.

Baumol, W., \& Bowen, W. (1966). Performing Arts, The Economic Dilemma: a study of problems common to theater, opera, music, and dance. New York: Twentieth Century Fund.

Becker, P. (2006). Social Change in America The Historical Handbook. Lanham: Bernan Press.

Bernanke, B. (1981). Bankruptcy, Liquidity, and Recession. The American Economic Review, 71(2), 155-159. Papers and Proceedings of the Ninety-Third Annual Meeting of the American Economic Association (May, 1981). http://dx.doi.org/10.1017/S105383721300045X

Bernanke, B. (2015a). The Courage to Act. New York: W.W. Norton.

Bernanke, B. (2015b). Monetary policy and inequality, The Brookings Institute. Ben’s Blog, June $1 . \quad$ [Online] Available: http://www.brookings.edu/blogs/ben-bernanke/posts/2015/06/01-monetary-policy-and-inequa lity

Berry, C. R., Burden, B. C., \& Howell, W. G. (2010). The president and the distribution of federal spending. The American Political Science Review. Menasha, 104(4), 783-800.

Blanchard, O. (2016). Slow growth is a fact of life in the post-crisis world. Financial Times.

Blanchard, O., Eugenio, C., \& Summers, L. (2015). Inflation and Activity: Two Explorations and Their Monetary Policy Implications. Peterson Institute for International Economics, Ideas, Working Papers Series, 15-19.

Blau, B. M. (2015). Income Inequality, Poverty, and the Liquidity of Stock Markets. [Online] Available: http://papers.ssrn.com/sol3/papers.cfm?abstract_id=2708500

Boulding, K. (1981). Evolutionary Economics. Beverly Hills, CA: Sage Publications.

Bovino, B. A., Petek, G. J., \& Chambers, J. B. (2014). How Increasing Income Inequality Is Dampening U.S. Economic Growth, And Possible Ways To Change The Tide. Standard and Poors Economic Research Report, 5. [Online] Available: http://www.ncsl.org/Portals/1/Documents/forum/Forum_2014/Income_Inequality.pdf

Broadberry, S. N. (1992). Manufacturing and the Convergence Hypothesis: What the Long 
Run Data Show. CEPR Discussion Papers 708, C.E.P.R.

Brunsden, J., \& McGee, P. (2016). Diesel car studies raise fresh fears. Financial Times.

Burgis, T. (2016). London’s dark money. Financial Times.

Caldararo, N. (2004). Sustainability: Human Ecology, and the Collapse of Complex Societies. Lewiston: The Edwin Mellen Press.

Caldararo, N. (2009a). Primitive and Modern Economics: Derivatives, Liquidity, Value, Panic and Crises, A Uniformitarian View. Form. Soc. Econ, 38(1), 31-51. http://dx.doi.org/10.1007/s12143-008-9029-2

Caldararo, N. (2009b). Caching, money, magic, derivatives, mana and modern finance. Journal of World Anthropology, Occasional Papers, III(2), 1-47. [Online] Available: http://wings.buffalo.edu/research/anthrogis/oldsite/JWA/V3N2/Caldararo-art.pdf

Caldararo, N. (2010). Derivatives and debt: The market as god and marketing as proselytizing. In C. V. Karsone (Ed.), Finance and Banking Developments. New York: Nova Science Publishing.

Caldararo, N. (2012). Some Evolutionary Aspects of Disease Avoidance. Saarbrucken: Scholar's Press.

Caldararo, N. (2013). Theory of banking: why banks exist and why we fear them. International Journal of Sociology and Anthropology, 5(4), 116-132. [Online] Available: http://www.academicjournals.org/journal/IJSA/article-full-text-pdf/4D781825338

Caldararo, N. (2013a). The Anthropology of Complex Economic Systems: Inequality, Stability and Cycles of Crisis. Lanham: Lexington Books.

Caldararo, N. (2014). The Credit Crisis. Saarbrucken: Scholars’ Press.

Caldararo, N. (2015). Local Resistance in the Era of Capitalist Globalization: Clash of Cultures in the 21st Century. IUP Journal of International Relations, 9(3), 7-22.

CBO (2012). Report on the Troubled Asset Relief Program. [Online] Available: https://www.cbo.gov/publication/43662

Cecchetti, S. G., \& Kharroubi, E. (2012). Reassessing the impact of finance on growth. Bank of International Settlements. Working Papers. [Online] Available: http://www.bis.org/publ/work381.pdf

Cipolla, C. (1976). Before the Industrial Revolution. New York: Norton \& Co.

Cock, J. (1980). Maids and Madams: A Study in the Politics of Exploitation. Johannesburg: Ravan Press.

Combes, P. P., Lafourcade, M., \& Thisse, J. F. (2008). Long-run spatial inequality in France: evolution and determinants. CEPR Policy Paper, 5. [Online] Available: http://voxeu.org/article/long-run-spatial-inequality-france-evolution-and-determinants 
DeLong, J. B. (2000). The triumph (?) of monetarism. Journal of Economic Perspectives, 14(1), 84-94.

Doctor, V. (2016). Mitsubishi emissions cheating scandal: Japan car maker allegedly falsified fuel mileage tests. Auto World News.

Donnan, S. (2026). World Bank loans at record level since financial crisis. Financial Times.

Dopfer, K. (2001). Evolutionary Economics: Program and Scope. Boston: Kluwer. http://dx.doi.org/10.1007/978-94-010-0648-4

Dumont, L. (1970). Homo Hierarchicus, the Caste System and its Implications. Chicago: University of California Press.

Durkheim, E. (1895). The Rules of the Sociological Record. New York: Free Press.

Federal Reserve Bank of St. Louis. (2016). Velocity of M2 money stock. [Online] Available: https://research.stlouisfed.org/fred2/series/M2V

Fleming, S. (2015). US jobs market still shy of full strength. Financial Times.

Flemming, S., \& Donnan, S. (2016). Household income tumbles in majority of US cities this century. Financial Times.

Ford, J. (2016). Mind the GAAP_-it gives a truer picture of companies' health. Financial Times.

Foroohar, R. (2016). Too many businesses want a piece of the financial action. Financial Times.

Foroohar, R. (2016a). The Makers and the Takers: the Rise of Finance and the Fall of American Business. New York: Crown Business.

Foster, G. (1965). Peasant society and the image of limited good. American Anthropologist, 67, 293-315. http://dx.doi.org/10.1525/aa.1965.67.2.02a00010

GAO. (2013). Causes and consequences of recent bank failures. Highlights. [Online] Available: http://www.gao.gov/products/GAO-13-71

Garzarelli, F. (2016). Central banks have safer options than a helicopter drop. Financial Times.

Goody, J. (2004). Capitalism and Modernity: The Great Debate. Malden: Polity.

Gordon, R. J. (2014). The Demise of U.S. Economic Growth: Restatement, Rebuttal, and Reflections. NBER Working Paper No. 19895.

Greenspan, A. (2014). The Map and the Territory 2.0. New York: Penguin Books.

Greenwood, R., \& Scharfstein, D. (2013). The growth of finance. Journal of Economic Perspectives, 27(2), 3-28. http://dx.doi.org/10.1257/jep.27.2.3

H2 Ventures and KPMG. (2016). FINTECH 100 Report. [Online] Available: 
http://www.fintechinnovators.com/

Hammar, K. (2015). Iceland Makes Strong Recovery from 2008 Financial Crisis. IMF Survey Magazine: Countries \& Regions. [Online] Available: http://www.imf.org/external/pubs/ft/survey/so/2015/car031315a.htm

Heilbroner, R. L. (1962). The Making of Economic Society. Englewood Cliffs: Prentice-Hall.

Henderson, P. (2012). Did Canadian banks receive a secret bailout? Financial Post.

Herskovits, M. (1952). Economic Anthropology (title changed from: Economic Life of Primitive Peoples. New York: Knopf, (originally published, 1940).

Hodgson, G. M. (2006). What are institutions? Journal of Economic Issues, XL(1), 1-25 http://dx.doi.org/10.1080/00213624.2006.11506879

Houlder, V., \& Dunkley, E. (2016). Banks face greater scrutiny over links to offshore companies in murky territories. Financial Times.

Hughes, J. (2016). Short View. Financial Times.

Hutchinson, E. P. (1967). The Population Debate. New York: Houghton Mifflin.

Inagaki, K. (2016). Toshiba takes \$2.3bn Westinghouse writedown. Financial Times.

Jones, C. (2016). German elite steps up pressure on ECB over bond buying. Financial Times.

Kamar, E. (1998). A Regulatory Competition Theory of Indeterminacy in Corporate Law. Columbia Law Review, 98(8), 1908-1959. http://dx.doi.org/10.2307/1123527

Kay, J. (2016). Complexity, not size is the real danger in banking. Financial Times.

King, M. (2016). The End of Alchemy: Money, Banking and the Future of the Global Economy. New York: Little, Brown.

LaHart, J. (2016). The S\&P 500 Earnings: Far worse than advertized. The Wall Street Journal.

Lanman, S. (2016). IMF urges China to tackle "High" corporate debt immediately. Bloomberg. [Online] Available: http://www.bloomberg.com/news/articles/2016-06-11/imf-urges-china-to-tackle-high-corpora te-debt-immediately

Lewin, J. (2016). Sharp rise in “fallen angels” outpaces total for 2015. Financial Times.

Marcus, G. (1990). Maids and Madams, a film by Mira Hamermesh. American Anthropologist, New Series, 92(2).

Mazower, M. (2016). Fresh ideas and lessons from the past are key to Europe's survival. Financial Times.

McCloskey, D. (2014). Equality is irrelevant if the poor are growing richer. Financial Times. 
Mercer, M. (2014). Getting workers back in the workforce, Pew Charitable Trusts. Stateline. Meyer, G. (2016). Goldman trades more gas than Exxon and Chevron. Financial Times.

Mian, A., \& Sufi, A. (2014). House of Debt: How They (and You) Caused the Great Recession and How We Can Prevent It from Happening Again. Chicago: University of Chicago Press.

Minerd, S. (2016). Splurge on negative rates is deepening the global liquidity trap. Financial Times.

Mulvany, L. (2015). The US is producing a record amount of milk and dumping the leftovers. Bloomberg. [Online] Available: http://www.bloomberg.com/news/articles/2015-07-01/milk-spilled-into-manure-pits-as-suppli es-overwhelm-u-s-dairies

National Employment Law Project (NELP). (2014). TRACKING THE LOW-WAGE RECOVERY: INDUSTRY EMPLOYMENT \& WAGES, Data Brief. [Online] Available: http://www.nelp.org/publication/tracking-the-low-wage-recovery-industry-employment-wage s/

National Environmental Health, Toxicology Information Program. (2016) Lead in Flint, Michigan water system, NIH, US National Library of Medicine. [Online] Available: https://sis.nlm.nih.gov/enviro/FlintLeadWater.pdf

Nightengale, A., \& Christie, N. (2015). Oil traders storing millions of barrels at sea on slump. Bloomberg. [Online] Available: http://www.bloomberg.com/news/articles/2015-01-09/oil-traders-seen-storing-millions-of-bar rels-at-sea-on-slump-1-

Nordhaus, W. D. (2006). Baumol's Diseases: A Macroeconomic Perspective. NBER Working Paper No. 12218.

Norfield, T. (2016). The City: London and the Global Power of Finance. New York: Verso Books.

Orth, J. V. (1987). The Judicial Power of the United States, the Eleventh Amendment in American History. New York: Oxford University Press.

Partnoy, F. (1997). F.I.A.S.C.O Blood in the Water on Wall Street. New York: W.W. Norton.

Partnoy, F. (2003). Infectious Greed: How Deceit and Risk Corrupted the Financial Markets. New York: Times Books.

Partnoy, F. (2005). A serious question for all the overpaid bankers. Financial Times.

Paulson, H. (2010). On the Brink. New York: Business Plus.

Piketty, T. (2014). Capital in the 21st Century. Cambridge: Belknap Press of Harvard University.

Pink, A. (2016). Taking “fair share of tax" to its logical conclusion. Financial Times. 
Polanyi, C. (1944). The Great Transformation. New York: Holt, Rinehart and Winston.

Polybius. (154 B.C.E). Histories. London: Penguin Books.

Reinhart, C., \& Rogoff, K. (2009). This Time is Different: Eight Centuries of Financial Folly. Princeton: Princeton University Press.

Ricardo, D. (1817). The Principles of Political Economy and Taxation. In P. Sraffa (ed.), The Works and Correspondence of David Ricardo. Cambridge: Cambridge University Press.

Rist, C. (1940). History of monetary and credit theory from John Law to the present day. New York: MacMillan.

Rostovtzeff, M. (1957). The Social and Economic History of the Roman Empire. Oxford: Clarendon Press, (originally published, 1926).

Sahlins, M. (1972). Stone Age Economics. Chicago: Aldine-Atherton.

Sahlins, M. (1988). Notes on the original affluent society (1968). Tribal Peoples and Development Issues. In J. H. Bodley (Ed.), Mayfield, Mountain View, 15-22.

Samson, A. (2016). US groups expand taste for buybacks. Financial Times.

Satter, R. (2016). Reports: Firm usurped name to hide money. The Associated Press.

Scannell, K., \& Houlder, V. (2016). The new Switzerland? Financial Times.

Scheve, K., \& Stasavage, D. (2016). Taxing the Rich: A History of Fiscal Fairness in the United States and Europe. Princeton: Princeton University Press. http://dx.doi.org/10.1515/9781400880379

Schumpeter, A. J. (1939). Business Cycles: A Theoretical Historical and Statistical Analysis of the Capitalist Process. Mansfield Centre: Martino Publications.

Sender, H. (2016). Blackstone navigated the property bust with aplomb. Financial Times.

Shierholz, H., \& Mishel, L. (2013). A Decade of Flat Wages, Economic Policy Institute. [Online]

Available: http://www.epi.org/publication/a-decade-of-flat-wages-the-key-barrier-to-shared-prosperity-a nd-a-rising-middle-class/

Shultz, W. J., \& Caine, M. R. (1937). Financial Development of the United States. New York, Prentice-Hall.

Skeel, D. A. (2012). States of bankruptcy. University of Chicago Law Review, 79(2), 677-735.

Smith, A. (1776). The Wealth of Nations. New York: Arlington House.

Spencer, H. (1873). Descriptive Sociology. New York: D. Appleton.

Strumpf, D. (2014). Companies’ Stock Buybacks Help Buoy the Market. The Wall Street Journal. 
Tainter, J. (1988). The Collapse of Complex Societies. Cambridge: Cambridge University Press.

Thomsen, P. M. (2011). How Iceland recovered from its near-death experience. IMF Direct [Online]

Available: https://blog-imfdirect.imf.org/2011/10/26/how-iceland-recovered-from-its-near-death-experie nce/

Wade, R. H. (2016). Scale-ups are the true engines of growth. Financial Times.

Webber, J. (2016). Law firm dismisses disclosure as media “witch hunt.” Financial Times.

Wheatley, J. (2016). Debt rises rapidly in emerging markets. Financial Times.

Wildau, G. (2016). Sluggish supply chain payments compound China’s debt woes. Financial Times.

Wildau, G. (2016a). China’s bad banks swell as defaults spread. Financial Times.

Wittfogel, K. (1938). New Light on Chinese Society; An Investigation of China's Socio-Economic Structure. New York, Institute of Pacific Relations.

Wittfogel, K. (1957). Oriental Despotism. New Haven: Yale University Press.

Wolf, M. (2016). Negative rates are a symptom of our ills. Financial Times.

Wolf, M. (2016). Worlds Apart. Financial Times.

Yang, Y., \& Wildau, G. (2016). Chinese credit growth slows as leadership warns of over leverage. Financial Times.

Zentner, E., \& Campbell, P. (2014). US Economics: Inequality and Consumption. Morgan Stanley. [Online] Available: http://www.morganstanleyfa.com/public/projectfiles/02386f9f-409c-4cc9-bc6b-13574637ec1 d.pdf

\section{Copyright Disclaimer}

Copyright for this article is retained by the author(s), with first publication rights granted to the journal.

This is an open-access article distributed under the terms and conditions of the Creative Commons Attribution license (http://creativecommons.org/licenses/by/3.0/). 